Oxford Bibliographies

\title{
Angela Carter
}

Nicoletta Caputo

University of Pisa

Table of Contents

Introduction

General Overviews

Monographs

Edited Collections

Bibliographies and Reference Works

Biographies

Interviews

Personal Reminiscences and Obituaries

Reviews

Criticism of Individual Works

Early novels up to 1972

The Passion of New Eve

Nights at the Circus

Wise Children

Fairy Tales

Short Stories

Essays and Journalism

Radio, Film and Television

The Gothic

Magic Realism

Feminism

Psychoanalysis

Postmodernism and History

The Grotesque and the Carnivalesque

Carter and Other (Women) Writers

Carter in the Panorama of Contemporary Fiction 


\section{Introduction}

Angela Carter (née Stalker) was born on 7 May 1940 in Eastbourne, Sussex. She spent much of her childhood in South Yorkshire with her maternal grandmother, a very strong woman who had a lasting influence on her. At the end of the war her family went back to London and, after leaving school, Carter worked briefly as a junior reporter for a local newspaper. In 1960 she married and went to Bristol, where she graduated in 1965, specializing in medieval literature. Her first novel, Shadow Dance, was published in 1966. The Magic Toyshop, which won the John Llewellyn Rhys Prize, followed in 1967. In 1969, after separating from her husband, she went to live in Japan for two years on the Somerset Maugham Travel Award she had won for her third novel, Several Perceptions. There, as she claimed in Nothing Sacred, she "learnt what it is to be a woman and became radicalized." In 1969 Heroes and Villain was also published. The essays she wrote for New Society (a selection of which were collected in Nothing Sacred, 1972) show her fascination with Japan. When in 1972 she returned to England, she stayed for a while in London; then she moved to Bath, but in 1976 the capital became her base again, as she settled in South London with Mark Pearce, who was to become her second husband and the father of Carter's son, Alexander, who was born in 1983. She supported herself teaching creative writing at universities in England and around the world (in the United States and Australia) and writing journalism. In this period, she also produced some of her most important achievements: the novels The Infernal Desire Machines of Doctor Hoffman (1972) and The Passion of New Eve (1977), the collections of short stories Fireworks (1974) and The Bloody Chamber and Other Stories (1979), and the controversial The Sadeian Woman (1979). Then, in 1984, what is generally considered Carter's masterpiece, Nights at the Circus, appeared, followed, in 1985, by another collection of short stories, Black Venus. Her last, flamboyant, novel, Wise Children, was published in 1991, just a few months before Carter's death of lung cancer, on 16 February 1992. In her writings, Carter undertook a materialist and feminist critique of western cultural past, as she relentlessly and challengingly probed fixed gender roles, and demystified culturally constructed myths of femininity. However, her ideological commitment went hand in hand with a playful - but nonetheless serious engagement with our cultural tradition, literary and otherwise. She combined narrative genres and modes (the Gothic, the picaresque, science fiction, fairy tales) to create highly imaginative, original, provocative and revisionary works, which were characterized by an exuberant, sensuous, often baroque prose and imagery.

\section{- General Overviews}

Criticism before 1992 was scanty, and it consisted essentially in reviews and interviews. Carter's popularity literally exploded after her (premature) death, and, in less than no time, she became the most read and widely studied contemporary British writer. Her books sold out only three days after she died and the early 1990 s assisted to what has been called a "Carter-craze." A consistent number of monographic studies and essay collections were published from 1994 onwards.

Monographs

The majority of the monographs selected for this category appeared in the years 1997-1998. They use widely different approaches to try to systematize the idiosyncratic and variegated production of the author. The most comprehensive volume is Gamble 1997, which offers an analysis of all of Carter's published fiction (both novels and short stories) plus a substantial amount of her non-fiction (most notably, her autobiographical essays), including The Sadeian Woman. The Bloody Chamber and The Sadeian Woman are also examined in Day 1998, together with all of Carter's novels. On the other hand, Lee 1997 and Peach 1998 focus exclusively on the novels. Cavallaro 2011 is the more selective, as is concentrates only on five texts, belonging to different periods of the author's production. Tonkin 2012 is more specific in concentrating on the decadent intertextual network in some of Carter's writings. Wisker 2003 is brief and is aimed at a different public (one still unfamiliar with Carter's oeuvre) with respect to the other monographic surveys included in the category.

- Cavallaro, Dani. The World of Angela Carter: A Critical Investigation. Jefferson, N.C. McFarland \& Company, 2011.

Following an introduction on "Carter's vision," the text perceptively examines a selection of Carter's major fiction. The chapters are also organized around themes and ideas central to Carter's production. The discussion is integrated with Carter's speculative perspectives on politics, society and aesthetics.

Day, Aidan. Angela Carter: The Rational Glass. Manchester: Manchester University Press, 1998.

The author argues that fantastical elements in Carter's fiction are firmly rooted in historicity and in a "rational, materialist, feminist base." The text, which is clearly written and is consistent with its premises, covers nearly all Carter's fictional production (excluding the radio plays and the stories in Fireworks and Black Venus), plus The Sadeian Woman. Important and substantial study.

- Gamble, Sarah. Angela Carter: Writing from the Front Line. Edinburgh: Edinburgh University Press, 1997. 
Scholarly, but accessible study of Carter's work (both fictional and non-fictional), which is particularly concerned with its socially subversive potential. In line with Carter's own materialist commitment, the study shows how the author managed to subvert accepted notions and conventions regarding the nature of history, women's place in society and the literary canon. Each of the three section investigates Carter's work in relationship to the decade in which it was written.

Lee, Alison. Angela Carter (English Authors Series). New York: Twayne, 1997.

Accessible text that examines and explains Carter's novels, drawing on episodes from her life and ideas from her nonfiction writings. The chronology, notes and references, selected bibliography, and index are also of use.

Peach, Linden. Angela Carter (Macmillan Modern Novelists). Basingstoke: Macmillan, 1998.

Carter's main works of fiction are discussed and organized, chronologically, around five thematic nuclei: "EuroAmerican Gothic and the 1960s," "Pain and Exclusion," "The Last Days" and "Illegitimate Power, Carnival and Theatre." The introduction also contains a brief, but interesting survey of criticism on Carter.

Tonkin, Maggie. Angela Carter and Decadence: Critical Fictions/Fictional Critiques. Basingstoke: Palgrave Macmillan, 2012.

The intertextual relation of some of Carter's fiction and The Sadeian woman with "decadent" writers like Edgar Allan Poe and Charles Baudelaire is acutely discussed to test the claim that Carter was subjugated to a fetishistic aesthetic that was antithetical to her feminism.

Wisker, Gina. Angela Carter: A Beginner's Guide. London: Hodder \& Stoughton, 2003.

A very short guide that offers an overview of Carter's production. The volume is primarily intended for those readers who are still unfamiliar with her work. It is interestingly focused on the reception of Carter's work.

Collections

Some of the volumes listed in this section (namely, Easton 2000 and Tucker 1998) consist of articles that had already appeared in journals. Among the collections that contain exclusively new materials, we find The Review of Contemporary Fiction special issue, which collects items that are not limited to academic essays, but include personal reminiscences, an interview and a bibliography. Sage 1994 is interesting because of the caliber of its contributors, who are not only affirmed critics, but also writers. Munford 2006 and, even more, AndermharPhillips 2012 urge for a critical revaluation of Carter and aim at offering revisionary criticism. In particular, they claim that, given the already huge and ever-growing body of scholarship on Carter, the author's oeuvre and legacy need to be re-assessed from new and original perspectives and put in a wider context, not only historical, but also of genre. Another useful miscellaneous volume on Carter, Bristow-Broughton 1997, is cited under "Feminism."

- Andermahr, Sonya, and Lawrence Phillips, eds. Angela Carter: New Critical Readings. London: Bloombsbury Publishing, 2012.

Starting from the premise that Carter "has been overly categorized as a postmodern folklorist," the collection aims at putting her oeuvre in a broader context, in order to make Carter emerge "not simply as a major feminist fabulist, but as a major late twentieth century writer tout court." Interesting and innovative, it expressly aims at "offering a revisionary account" of Carter's oeuvre.

"Angela Carter/Tadeusz Konwicki." The Review of Contemporary Fiction 14.3 (Fall 1994).

This journal special issue contains fifteen essays on Carter and her oeuvre, which include: two personal reminiscences (by Robert Coover and Scott Bradfield), an interview ("A Conversation with Angela Carter By Anna Katsavos," which can also be found online: http://www.dalkeyarchive.com/a-conversation-with-angelacarter-by-anna-katsavos/) and a bibliography of primary texts, which includes miscellanies in which her works appeared.

Easton, Alison, ed. Angela Carter (New Casebooks). Basingstoke: Palgrave Macmillan, 2000.

The collection offers a significant selection from the many different responses Carter's works have evoked over the past twenty years. It also interestingly identifies a number of fields of development, which include a more thorough historicization of her production and a more cogent analysis of her dialogue with twentieth-century key thinkers.

- Munford, Rebecca, ed. Re-visiting Angela Carter: Texts, Contexts, Intertexts. Basingstoke: Palgrave Macmillan, 2006.

Focused on intertextuality, this rich collection reappraises key literary and cultural influences on Carter (Shakespeare, de Sade, the Gothic, Japan) and throws light on neglected connections (Jean-Luc Godard, Marcel Proust, Charles Dickens, surrealism). The introduction, which is concerned with "Carter and the Politics of intertextuality," is also a helpful contribution to the contemporary debate on intertextual theory.

- Sage, Lorna, ed. Flesh and the Mirror. Essays on the Art of Angela Carter. London: Virago, 1994. 
In this collection, one of the major experts on Carter has assembled a number of valuable contributions by renowned writers and critics such as Margaret Atwood, Laura Mulvey, Marina Warner and Hermione Lee, who discuss Carter's fiction, non-fiction, radio plays and films.

- Tucker, Lindsey, ed. Critical Essays on Angela Carter (Twayne Critical Essays). London: Prentice Hall International, 1998.

In this very useful collection, some of the best scholarly essays on Carter (some of which are discussed independently in the present article) are reprinted, together with Carter's own "Notes from the Front Line." Even if no chief fictional work is neglected, the majority of the essays concentrate on the fairy tales and on Nights at the Circus.

\section{- $\quad$ Bibliographies and Reference Works}

As has already been noted, the sudden interest in Carter that followed her death gave rise to a great abundance of criticism whose quality is, sometimes, disputable. This is why guides that help to orient the reader in the jungle of the critical debate are needed. Gamble 2001 offers a useful tool for Carter research. Unfortunately, it is more than a decade old and much has been written on Carter from the time it was published (2006, for instance, saw an abundance of criticism on the author). Thus, Gamble has to be integrated with the MLA International Bibliography which, of course, is not selective, but is, by definition, the most up-to-date reference tool. Stoddart 2007 and Milne 2007 offer guides to individual works (arguably the most widely studied ones in Carter's production), but are aimed at very different categories of readers.

- Gamble, Sarah. The Fiction of Angela Carter. A Readers' Guide to Essential Criticism. Basingstoke:

Palgrave Macmillan, 2001.

The critical reception of Carter's oeuvre is examined. The various chapters deal with Carter's fiction (including The Sadeian Woman, which is, indeed, non-fiction) in chronological order. Gamble draws on interviews, articles, books and Carter's own pronouncements on her life and art. Extremely useful and well-edited.

- Milne, Andrew. Angela Carter's "The Bloody Chamber" - A Reader's Guide. Paris: Editions Le Manuscript, 2007.

Aimed at secondary school students. Each chapter is devoted to a tale in the collection. It begins with a short synopsis, which is followed by a commentary of the key notions and themes. Intertextual elements are also dealt with. The language is simple and plain. A short list of internet sites follows each chapter.

MLA International Bibliography.

Provides a subject index for all scholarly articles and books on modern languages, literatures, folklore, and linguistics. Compiled by the Modern Language Association of America since 1926. The electronic version includes the Bibliography's entire print run, and currently contains more than 2 million records. Presently, it counts about 500 entries for Carter, which are both works by Carter and on Carter from 1970 onwards.

- Stoddart, Helen. Angela Carter's Nights at the Circus (Routledge Guides to Literature). New York:

Routledge, 2007.

Aimed at those who want to study the novel in detail, it offers an accessible introduction to its text and contexts. It also provides a critical history - which is organized thematically - and a selection of new critical essays. Cross-references between the sections and suggestions for further readings are also of use.

\section{- $\quad$ Biographies}

This category is variegated, but it is an unavoidable point of departure for getting to know the author in depth. As a matter of fact, knowing Carter's view of culture and society and what she had to say about her own writing is fundamental for anyone who wants to approach her oeuvre. Equally important is knowing what the people who were close to her had to say about her personality and work. This because, as Sage (1994) put it: Carter "refus[ed] to observe any decorous distinction between art and life." A full-length authorized biography by Edmund Gordon (Angela Carter: The Biography) will be published in 2016.

\section{○ $\underline{\text { Interviews }}$}

The interviews Carter gave are numerous and sometimes they may appear repetitive in contents (that is because most of them were given around 1985), but each of them offers significant insights and constitutes an important addition to our knowledge of the author. Some are quite difficult to find, especially Bono 1986, Cagney Watts 1985 and Del Rey 1991, but the enterprise of getting to read as many interviews as possible is worth pursuing. Particularly interesting and also easy to find in libraries are Goldsworthy 1985, Haffenden 1985 and Kenyon 1992. "The Company of Angela Carter" (1985) is also online at the following link: http://amielandmelburn.org.uk/collections/mt/pdf/85 01 20.pdf. The two video recordings (Appignanesi 1985 and Mars Jones 1984) are worth watching too. Other interesting interviews are Sage 1977 (cited under "Personal Reminiscences and Obituaries"), Sage 1992 (cited under "Wise Children") and the one included in The Review of Contemporary Fiction 1994 (cited under "Collections"). 
- Appignanesi, Lisa. Angela Carter with Lisa Appignanesi (Writers in Conversation). London: Institute of Contemporary Arts (ICA), 1985.

48 minute video recording. Carter discusses her life and her writing. Topics of discussion include: English fiction as playground of the bourgeoisie, tales as interpretations of the subconscious, political writing vs. writing which is political, subverting stereotypes, using fairy-tales to reinterpret history.

- Bono, Paola. "Intervista con Angela Carter." DWF Donna Woman Femme 2 (1986): 94-103.

In Italian. Rich and original. Carter discusses: artistic creation; femininity; women and writing; her writing as an exploration of narrative genres and as "intellectual bricolage"; myths and folklore; the reasons behind her use of intertextuality.

- Cagney Watts, Helen. “Angela Carter: An Interview." Bête Noir 8 (August 1985): 161-176.

Carter discusses how Fevvers in Nights at the Circus originated out of the writing of The Sadeian Woman.

"The Company of Angela Carter. An Interview." Marxism Today, January 1985: 20-22.

The author talks about her political engagement in writing fiction. Topics of discussion include The Company of Wolves and folklore.

- Del Rey, Santiago. "Feminismo y brujerña. Entrevista con Angela Carter." Quimera: Revista de Literatura 102 (1991): 20-27.

In Spanish. Carter discusses feminism, women's literature and Jorge Luis Borges, who is identified as the South American author who most influenced her writings.

- Goldsworthy, Kerryn. "Angela Carter: Interview." Meanjin 44.1 (March 1985): 4-13.

The author discusses the relationship between reading and writing, the process of writing, and, less extensively, "Black Venus" and the sense of landscape and the city in The Passion of New Eve and Nothing Sacred.

- Haffenden, John. "Angela Carter." In Novelists in Interview, 76-96. New York: Methuen, 1985.

Undoubtedly, one of the best interviews Carter ever gave. She talks about Gabriel García Márquez and magic realism; The Magic Toyshop; her rewriting of fairy tales; The Passion of New Eve, and, above all, Nights at the Circus.

- Kenyon, Olga. "Angela Carter." In The Writer's Imagination: Interviews with Major International Women Novelists, 23-34. Bradford, UK: University of Bradford Print Unit, 1992.

Often cited in scholarly works on Carter, the author talks about various topics, particularly interesting is what she has to say about The Passion of New Eve.

Mars Jones, Adam. Angela Carter with Adam Mars Jones (Writers in Conversation). London: Institute of Contemporary Arts (ICA), 1984.

44 minute video recording. In which Carter talks with critic and novelist Adam Mars Jones about her most recent book, Nights at the Circus, and discusses the terrain of fiction and fantasy.

- Mortimer, John. "The Sadeian Woman: Angela Carter." In In Character, 43-47. Harmondsworth: Penguin Books, 1983.

Carter is interviewed for The Sunday Times. Originally published as "The Stylish Prime of Miss Carter," Sunday Times, 24 January 1982: 36.

Snitow, Ann. "Angela Caner. Wild Thing: Conversation with a Necromancer." Village Voice Literary Supplement 75.14 (June 1989): 16- 17.

Carter is defined as a "necromantic dreamer fascinated by rationality."

- $\quad$ Personal Reminiscences and Obituaries

In this category Lorna Sage figures large with three works, since she was the preeminent critic on Carter during her lifetime and in the years that succeeded her death. Her 1977 interview with Carter is probably the first published academic assessment of the writer's work. The biographical works by Sage (1994) and Gamble (1996) excellently succeed in linking her work to her life and prove illuminating. Gamble 2006 also places Carter in her historical, social and cultural context. Clapp 2012 is very short and far from systematic, but it inventively offers interesting glimpses of Carter's uncommon personality, as also Moorcock 2006 does. The obituaries (represented, here, by Atwood 1992, Rushdie 1992 and Sage 1992), in depicting the author either as a witch or the fairy godmother, contributed to the "mythologizing" of Carter - who was, paradoxically, a committed demythologizer - that followed her death. This phenomenon that is discussed in Makinen 1992 (cited under "Fairy Tales").

Atwood, Margaret. "Magic Token through the Dark Forest." The Observer, 23 February 1992: 61.

This memorial suggestively identifies Carter's relentless inquisitiveness and zest for life in all its different aspects as the driving force at the heart of her inexhaustible creativity. 
- Clapp, Susannah. A Card from Angela Carter. London: Bloombsbury Publishing, 2012.

Original (and slim) biography that takes its cue from the postcards that Carter sent to her friend, the journalist Susanna Clapp, who was also her literary executor, in the eighties. The witty, irreverent, imaginative, pungent messages that accompany the sometimes awfully kitsch cards (which are reproduced in the book) throw light on Carter's humorous and anarchic personality.

Gamble, Sarah. Angela Carter. A Literary Life. Basingstoke: Palgrave Macmillan, 2006.

Carter is placed within the social, political and cultural context of her times. Relying on Carter's own autobiographical articles, as well as her fiction, journalism, radio plays and TV programs, her engagement with crucial issues such as English identity, class, politics and feminism is investigated.

- Moorcock, Michael. "Introduction." In Angela Carter. Expletives Deleted. Selected Writings. London: Vintage Books, 2006.

Account of Moorcock and Carter's friendship that focuses, in particular, on the time of the writer's final illness. It includes a letter she sent Moorcock. Interesting glimpses of Carter's extraordinary personality: her literary tastes, her generosity with friends and her unfaltering sense of humor.

- Rushdie, Salman. "Angela Carter, 1940-92: A Very Good Wizard, a Very Dear Friend," New York Times Book Review, March 1992: 3.

In this short obituary, Carter's friend Salman Rushdie skillfully and poetically mixes personal reminiscences (the first time they met in 1979 and her fight against cancer, for instance) with acute observations about her value as an artist and about her last novel, Wise Children.

- Sage, Lorna. "The Savage Sideshow. A Profile of Angela Carter". The New Review 39/40 (June/July 1977): 51-57.

One of the first surveys of Carter's fiction (up to The Passion of New Eve). It is very synthetic, but it remains, nevertheless, a classic. The survey introduces an interview with the author.

- Sage, Lorna. "Death of the Author," Granta: Biography 41 (Autumn 1992): 233-255. Reprinted in Good as

Her Word: Selected Journalism. Edited by Sharon Sage and Victor Sage. London: HarperCollins Fourth Estate, 2003.

Starting from some remarks upon the reactions to Carter's departure, this obituary originally retraces the stages of Carter's life ("Beginning", "Middle", "Ending"), interspersing Sage's reminiscences and considerations with bits of Carter's writings and personal letters.

- Sage, Lorna. Angela Carter (Writers \& Their Work). Plymouth: Northcote House, 1994.

Carter's first biography. Concise, but authoritative. Carter's work is linked to her life and her character in illuminating ways. It is a much expanded version of the Granta obituary and it retains the same structure. The chronological presentation of Carter's writings flows evenly and cohesively. The select bibliography contains a very useful section on Carter's "Uncollected Material."

\section{- $\quad$ Reviews}

All the reviews in this category belong to the period following the publication of Nights at the Circus, when Carter's popularity and critical acclaim reached international levels, but scholarly and academic research still tended to neglect her. This is why reviews are often illuminating. The ones selected here are mainly focused on Nights at the Circus (Glendenning 1984, Mars-Jones 1984, Wood 1994) and Wise Children (Oates 1992, Parrinder 1991, White 1991). They are never banal, and engage, instead, in a lively dialogue with Carter's texts. Some of them (notably, Mars-Jones 1984, for instance) do not seem to fully grasp the significance of the work they are dealing with, nonetheless they prove invariably stimulating. Sage is, as usual, worth reading because she is, perhaps, the most acute interpreter of Carter. Bayley 1992 offers a discussion of a number of Carter's writings that were re-issued after her death.

- Bayley John. "Fighting for the Crown." The New York Review of Books 39.8 (23 April 1992): 9-11.

Survey of Carter's production that takes into account the various forms fantasy assumes into her work. Wise Children, Love, The Bloody Chamber, Heroes and Villains, The Infernal Desire Machines of Dr. Hoffman, Come Unto These Yellow Sands and The Sadeian Woman are discussed. Bayley, however, laments the politicization of Carter's work.

- Craig, Patricia. "Angela and the Beast." London Review of Books, 5 December 1985: 24.

Review of the collection Black Venus and of Come Unto These Yellow Sands

- Glendenning, Victoria. "Carter's Magical Mystery Tour." The Sunday Times, 30 September 1984.

Review of Nights at the Circus celebrating Carter's sophisticated artistry.

- Mars-Jones, Adam. "From Wonders to Prodigies: Angela Carter's Nights at the Circus." The Times Literary Supplement, 28 September 1984: 1083. 
The review concentrates on the complex play of narrators and points of view in Nights at the Circus, but its disappointing analysis of parts 2 and 3 of the novel shows the critic's failure to come to terms with Carter's highly idiosyncratic voice.

Oates, Joyce Carol. "Comedy Is Tragedy that Happens to Other People: Wise Children by Angela Carter." The New York Times Book Review, 19 January 1992: 7.

Review focusing on the eccentric character of the novel and on its peculiarly postmodern playful treatment of traditional genres.

Parrinder, Patrick. "It's Only a Paper Moon: Wise Children by Angela Carter." London Review of Books, 13 June 1991: 3.

Review that relates Carter's last novel to her previous production and reads Wise Children as a "carnivalesque history of the English theatre."

Sage, Lorna. "Breaking the Spell of the Past." Times Literary Supplement, 18 October 1985: 1169.

Review of the stories in Black Venus and, less relevantly, of Come Unto These Yellow Sands. Carter is seen as an "addicted re-writer" who aims at "escaping from tales already told."

White, Edmund. "Grand, Buffoonish and Tender: Angela Carter's Wise Children." Times Literary Supplement, 7 June 1991: 22.

Review stressing Carter's drawing on a "collective conscious" for this novel.

Wood, Michael. "Stories of Black and White." London Review of Books, 4-17 October 1984: 16.

Review of Nights at the Circus that concentrates on intertextuality.

\section{- $\quad$ Criticism of Individual Works}

The most celebrated texts - namely: The Passion of New Eve (1977), The Bloody Chamber and Other Stories (1979), Nights at the Circus (1984) and Wise Children (1992) - have received greater critical attention and have their own category in this section. In addition, the texts that are discussed in articles and essays that are cited in other categories will be indicated on each occasion.

- $\quad$ Early novels up to 1972

Early novels have received little critical attention. One has to turn to the monographs and the collections to find (sparing) discussions of Shadow Dance (1966), Several Perceptions (1968), Heroes and Villains (1969) and Love (1971). This is particularly true of Several Perceptions, which has got only one citation (in Spanish) in the MLA Bibliography, in spite of the fact that it won the Somerset Maugham Award. Greater critical attention has been given to The Magic Toyshop (1967) and, even more, to The Infernal Desire Machines of Dr. Hoffman (1972), which was the novel Carter herself selected when asked by Olga Kenyon in 1992 whether she had a personal favorite. Pearson 1999 examines intertextuality in Carter's first five novels. Karpinsky 2000 and Yoshioka 2006 concentrate on Heroes and Villains, while Manlove 1992 focuses on The Infernal Desire Machines of Dr. Hoffman, which is also discussed in: Neumeier 1996 (cited under "The Gothic"), Zamora 1995 (cited under "Magic Realism"); Dimovitz 2009, Punter 1984 and Schmidt 1989 (all cited under "Psychoanalysis"); Jordan 1992 ( cited under "Postmodernism and History"); Kilic 2009 (cited under "Carter and Other (Women) Writers"), and Robinson 1991 (cited under "Carter in the Panorama of Contemporary Fiction"). Heroes and Villains is also dealt with in López 2007 (cited under "Carter and Other (Women) Writers").

- Karpinski, Eva C.: "Signifying Passion: Angela Carter's Heroes and Villains as a Dystopian Romance."

Utopian Studies: Journal of the Society for Utopian Studies 11.2 (2000): 137-51.

One of Carter's most neglected and most misunderstood novels is read as an experimentation of the generic framework of a "dystopian romance" that accommodates the author's combined interest in social and sexual relations. In this way, the novel is seen as an integral part of Carter's demythologizing venture.

- Manlove, Colin. "In the Demythologising Business: Angela Carter's The Infernal Desire Machines of Dr.

Hoffman (1972)." In Twentieth-Century Fantasists: Essays in Culture, Society and Belief in Twentieth

Century Mythopoeic Literature, 148-160. Edited by Kath Filmer. New York: St. Martin's Press, 1992.

In spite of the title of the essay, Carter's novel is seen as simply thematizing "the making of fantasy itself" and as a postmodern novel in which "no evident social, political or even sexual meaning" can be found.

Pearson, Jacqueline: "'These Tags of Literature': Some Uses of Allusion in the Early Novels of Angela

Carter." Critique: Studies in Contemporary Fiction 40.3 (1999): 248-56.

Allusiveness is seen as one crucial technique by which Carter balances the "antithetical impulses" at work in her novels: the demythologizing and the celebratory and utopian. This article originally investigates Carter's "self-conscious, sometimes playful, sometimes deeply critical, intertextuality" in her early novels (all of them), where this aspect is usually disregarded.

Yoshioka, Chiharu. "Dialectic of Enlightenment in the 1960s Gothic: Angela Carter's Heroes and Villains." Gothic Studies 8.2 (2006): 68-79. 
Shows how Carter used genre fiction as political discourse in a novel its author wanted programmatically to be a "Gothic novel." It also shows how in Heroes and Villains the Gothic was a means for Carter "to tell a story of herself and her generation."

\section{- The Passion of New Eve}

The Passion of New Eve (1977) is Carter's seventh novel and it is one of the most widely studied both because of its weird and controversial subject and because of its complexity, which invites a variety of critical approaches. Ahearn 2000 examines a peculiar kind of intertextuality in the novel, while Rubinstein 1993 reads it in relation to feminist theory, as Rubinson 2000 (cited under "Feminism") does. Caputo 2002 and Carroll 2011 investigate the implications of the protagonist's transgender experience, while in Lee 1996 this same experience is connected to reader response issues. Transgendered identity is, again, central in Hobbs 2004 (cited under "Carter and Other (Women) Writers"). In Pérez-Gil 2007, instead, it is psychoanalysis that takes center stage. The novel is also discussed in: Dimovitz 2009, Punter 1984 and Schmidt 1989 (all cited under "Psychoanalysis"), and Jordan 1992 (cited under "Postmodernism and History"). It has to be noted that the last four essays analyze The Passion of New Eve in conjunction with The Infernal Desire Machines of Doctor Hoffman, and this is far from surprising, since the two novels are similar under more than one aspect, from their speculative nature to their science fiction setting. Finally, Sage 2001 (cited under "Carter in the Panorama of Contemporary Fiction") highlights the pivotal role of the novel in Carter's career.

Ahearn, Edward J. "The modern English visionary: Peter Ackroyd's Hawksmoor and Angela Carter's The Vision of New Eve." Twentieth Century Literature 46.4 (2000): 453-69.

Discusses how The Passion of New Eve is rooted in an apocalyptic and visionary tradition that reaches back to William Blake. To do this, the article traces the dense network of references to occult and apocryphal traditions.

- Caputo, Nicoletta. "Angela Carter's The Passion of New Eve (1977): Sexual Transmutation as Psychophysical Exile." In Displaced Persons: Conditions of Exile in European Culture, 138-148. Edited by Sharon Ouditt. Aldershot: Ashgate, 2002.

Relying on Carter's theoretical assertions in The Sadeian Woman and on feminist notions of gender as performativity, the article shows how Evelyn/Eve's psycho-physical exile - which springs from a gendertransgressive experience - can only find an end with the demystification of all the stereotyped versions of sexuality the protagonist has met in his/her literal and metaphorical journey.

- Carroll, Rachel. "'Violent Operations': Revisiting the Transgendered Body in Angela Carter's The Passion of New Eve." Women: A Cultural Review 22. 2-3 (2011): 241-255.

Representations of the transgendered body in The Passion of New Eve are examined, and both Carter's novel and its reception are revisited from the perspective of transgender theory. Interesting in its attempt to explore tensions between feminist and queer positions on the politics of sexed identity.

- Lee, Alison. "De/Engendering Narrative: Angela Carter's New Eve(lyn)." In Ambiguous Discourse: Feminist Narratology and British Women Writers, 238-249, Edited by Kathy Mezei. Chapel Hill and London: The University of North Carolina Press, 1996.

Lee argues that the narrator's gender shifting makes it difficult for the reader to pin down the gender of the narrative voice at specific moments and "makes narrative identity as complex as gender identity." Focalization is, thus, undetermined. It is precisely "the multiplicity, the undermining of binaries" that makes Carter's text feminist in both its story and its narrative structure.

- $\quad$ Pérez-Gil, Maria del Mar: "The Alchemy of the Self in Angela Carter's The Passion of New Eve." Studies in the Novel 39.2 (2007): 216-34.

It interestingly argues that in The Passion of New Eve (which is defined as "Carter's most iconoclastic novel") the author satirically demythologizes Carl Jung's assumptions concerning the archetypal feminine and the androgynous self. This, by reproducing many of the principles on which Jungian psychology is based in order to subvert them.

e select bibliography contains a very useful osis in Angela Carter's The Passion of New Eve and Lois Gould's A Sea-Change." Tulsa Studies in Women's Literature 12.1 (Spring, 1993): 103-118.

The novel is read in relation to Clément and Cixous's "newly born woman" (la jeune née) - at the time not published in English translation yet - and Gilbert's representations of gender anomalousness. However, Rubinstein sees Carter's New Eve as unable to re-define and go beyond what Gilbert calls the "established paradigms of dominance and submission."

\section{Nights at the Circus}

Nights at the Circus is Carter's most popular, most celebrated and most widely studied text. In fact, it is the novel with which the author finally reached international critical acclaim. If only four titles have been selected for this category it is simply because the novel figures large elsewhere. All the essays in "The Grotesque and the 
Carnivalesque," for instance, deal with Nights at the Circus. As Boehm 1995 claims, however, the novel has often been misread. Caputo 2010 explores the intertextual texture of the novel; Christinidis 2012 reads it as a deconstruction of the traditional Bildungsroman and Finney 1998 emphasizes its fictionality. Again, the extreme, almost unruly, complexity of the novel, joined with Carter's bold incursions into disparate narrative genres and modes justify a great variety of critical approaches: the presence of the Gothic is explored in Munford 2002 (cited under "The Gothic"); that of magic realism in Hegerfeldt 2002, Sceats 2005, Zamora 1995 (all cited under "Magic Realism") and Armitt 2000 (cited under "Carter in the Panorama of Contemporary Fiction"). Neither has the novel's firm rootedness into feminism and psychoanalytic theory gone unnoticed, as Fernihough 1997, Jordan 1992 (both cited under "Feminism") and Schmidt 1989 (cited under "Psychoanalysis") testify. Last, but not least, Botescu-Sireteanu 2010 and Jordan 1992b investigate the connection between feminism and postmodernist strategies, while the viable coexistence between materialism and postmodernism in Nights at the Circus is probed by Michael 1994 (all cited under "Postmodernism and History"). Robinson 1991 (cited, again, under "Carter in the Panorama of Contemporary Fiction") relies also on this text to set up a dialogue between feminist critical theory and contemporary women's fiction.

- Boehm, Beth E. "Feminist Metafiction and Androcentric Reading Strategies: Angela Carter's Reconstructed

Reader in Nights at the Circus. Critique: Studies in Contemporary Fiction 37.1 (Fall 1995): 35-49.

Two reviews of Carter's novel produced by Adam Mars Jones and Carolyn See - for the Times Literary Supplement and The New York Times Book Review respectively - are discussed as examples of "misreadings" of this complex feminist metafiction novel.

- Caputo, Nicoletta. 'New Wine in Old Bottles': il bricolage intellettuale di Angela Carter in Nights at the

Circus. Arezzo: Bibliotheca Aretina, 2010.

In Italian. The monograph traces the thick intertextual network of allusions and influences in the novel and highlights the ideological weight subsumed to their exuberant playfulness. The chapters deal with: feminism, psychoanalysis and Marxism, the gothic and the picaresque, the intertextual play, the carnival, magic realism.

Christinidis, Georgia. "Radical Transformation: Angela Carter's Adaptation of the Bildungsroman." Textual

Practice 26.3 (September 2012): 467-487.

The novel is read as a powerful critique of the optimism that underlies the classical Bildungsroman, which is seen as a means to legitimize the status quo. Nights at the Circus presents a series of disruptions of narrative continuity and transgressions of logicality which constitute significant opportunities that must be seized in order to attain social change.

Finney, Brian. "Tall Tales and Brief Lives: Angela Carter's Nights at the Circus." Journal of Narrative

Technique 28 (1998): 161-185.

Reading that sees deceitfulness at the core of Nights at the Circus. Starting from Carter's assertion that the novel is "a statement about the nature of fiction," the essay explores the ways in which it foregrounds its own fictionality and its capacity to dazzle.

\section{- Wise Children}

The pyrotechnic exuberance of Carter's last novel has been widely praised and, at times, Wise Children has even been declared Carter's best fictional achievement. Nevertheless, it has not received as much critical attention as Nights at the Circus. The novel is discussed by the author in Sage 1992. The Shakespearean subtext of Wise Children is the focus of all the other essays listed in this category. Hegerfeldt 2003 concentrates on the ideological significance of Carter's playfully transgressive re-use of the Bard. Apfelbaum 1998 reads the novel as performance criticism of Shakespeare and Pedot 2010 as an apology for illusion. Bowers 2004 (cited under "Magic Realism") chooses this novel to exemplify Carter's use of magic realism, while both Mohr 1995 and Roessner 2002 (cited under "Carter and Other (Women) Writers") select this novel to draw parallels with other women novelists.

Apfelbaum, Roger. "Welcome to Dreamland': Performance Theory, Postcolonial Discourse, and the Filming of A Midsummer Night's Dream in Angela Carter's Wise Children." In Shakespeare and the Twentieth Century: The Selected Proceedings of the International Shakespeare Association World Congress, Los Angeles, 1996, 183-193. Edited by Jonathan Bate, Jill L. Levenson, and Dieter Mehl. Newark: University of Delaware Press, 1998.

Argues that Wise Children not only shows how "Shakespeare" changed in the course of the twentieth century, but is also engaged in performance criticism of Shakespeare. True to her demythologising venture, in this novel Carter would prove that Shakespeare performance is "a tool for cultural, political, colonial, economic, and quasi-religious purposes."

Hegerfeldt Anne. "The Stars that Spring from Bastardising: Wise Children Go for Shakespeare." Anglia. Zeitschrift für Englische Philologie 121. 3 (2003): 351-372. 
The essay looks at how Carter's last novel deconstructs the binary oppositions legitimate/illegitimate, high/low which function as ideological instruments of domination and exclusion - and replaces them with more inclusive notions of family and culture, promoting, in this way, a vision of a non-hierarchical, pluralistic society. A close reading of the novel that interestingly illuminates social and political issues.

Pedot, Richard. "'49 Bard Road': le mythe shakespearien dans Wise Children d'Angela Carter." Etudes Anglaises 63.4 (2010): 425-436.

In French. Sees the novel as an apology for illusion and its paradoxical power - due to its liminal position between tragedy and comedy - to help us recognize and accept reality.

- Sage, Lorna. "Angela Carter interviewed by Lorna Sage." In New Writing, 185-193. Edited by Malcolm

Bradbury and Judy Cooke. London: Minerva in association with the British Council, 1992.

The interview is chiefly concerned with Carter's recently published novel Wise Children. Carter's voice alternates with reported speech. Very useful because numerous aspects of the work are discussed.

Fairy Tales

The Bloody Chamber and Other Stories is seen in Palmer 1987 (cited under "Feminism") as a turning point in the writer's career. Carter's fairy tales have been widely anthologized and studied. In this category, we find some of the first critical assessments of Carter, which have, by now, become classics. They are: Bryant 1981, which draws a parallel between Carter's "Beauty and the Beast" and cinema, Duncker 1984, which is critical of Carter's revisionist fairy tales, and Lokke 1988, which focuses on Carter's subversive use of the grotesque. Unavoidable is the full-length study Roemer-Bacchilega 2001 for the variety of approaches and the range of texts it deals with. As a matter of fact, it must never be forgotten that Carter's fairy tales are not limited to the ones collected in The Bloody Chamber and Other Stories, but they were also published in other short story volumes. Other aspects of Carter's treatment of fairy tales are discussed, briefly, in Warner 1990 and, at length, in Dutheil De La Rochère 2013. The "decolonizing" and subversive import of Carter's feminist revision of the fairy-tale genre is discussed in Makinen 1992 and Sheets 1991. The central theme of "The Lady of the House of Love," vampirism, is read as a means to explore gender issues and "postmodern historicity" in Sceats 2001 (cited under "The Gothic") and Wilson 1989 (cited under "Postmodernism and History"), respectively. The psychoanalytic substratum of "Wolf-Alice" is, finally, explored in Dimovitz 2010 (cited under "Psychoanalysis").

Bryant, Sylvia. "Re-Constructing Oedipus Through 'Beauty and the Beast'." Criticism 31 (1981): 439-453.

Interesting study of Carter's revisionist (and "myth-breaking") re-writing of "Beauty and the Beast" against Jean Cocteau's 1946 film text La Belle et la Bête. Bryant has recourse to the theories of the feminist film critics Teresa de Lauretis and Laura Mulvey in her analysis.

- Duncker, Patricia, "Re-Imagining the Fairy Tales: Angela Carter's Bloody Chambers." Literature and History: A New Journal for the Humanities 10.1 (Spring 1984): 3-14.

Critical of Carter's idea about the nature and function of fairy tales and also of her rewritings of the tales. Argues that Carter, like heterosexual feminists in general, "has no conception of women's sexuality as autonomous desire." According to Duncker, "The Bloody Chamber" is the only tale that "carries an uncompromisingly feminist message."

Dutheil De La Rochère, Martine Hennard. Reading, Translating, Rewriting. Angela Carter's Translational

Poetics. Detroit, MI: Wayne State University Press, 2013.

Through a close analysis of Carter's translations and adaptations of fairy tales, the volume studies the impact of Carter's translation of Charles Perrault's Histoires ou contes du temps passé on her own rewritings of fairy tales. Such a scrutiny interestingly shows how Carter's translations reclaim Perrault's morals for materialist and feminist goals.

- Lokke, Kari E. "Bluebeard and The Bloody Chamber: The Grotesque of Self-Parody and Self-Assertion." Frontiers 10.1 (1988): 7-12.

Based on Bakhtin's and Kayser's studies on the grotesque, it explores how Max Frisch's and Angela Carter's tales use the grotesque as "an unsettling vehicle for exposing, through exaggeration, dark humour, and irony, the brutality of traditional patriarchal attitudes towards women." Carter's story is interpreted as a challenge to sadomasochism.

Makinen, Merja. "Angela Carter's The Bloody Chamber and the Decolonization of Feminine Sexuality." Feminist Review 42 (Autumn 1992): 2-15.

Makinen acutely notes how the mythologizing of Carter that followed her death - when she was unanimously saluted as either a white witch or a fairy godmother - tended to obscure and neutralize the dangerous and uncomfortably problematic nature of her oeuvre. Then, she proceeds to emphasize the aggressive subversiveness of the writings of what she defines "the avant-garde literary terrorist of feminism."

- Roemer, Danielle M., and Cristina Bacchilega, eds. Angela Carter and the Fairy Tale. Detroit MI: Wayne State University Press, 2001. 
Originally published (in 1998) as a special issue of the journal Marvels and Tales, the collection contains scholarly essays, fiction, personal reminiscences, and interviews. It investigates Carter's re-use of the fairy-tale genre, not only in the tales published in The Bloody Chamber and in other short story collections, but throughout her novels and fiction in general.

Sheets, Robin Ann. "Pornography, Fairy Tales, and Feminism: Angela Carter's 'The Bloody Chamber'." Journal of the History of Sexuality 1. 4 (April 1991): 633-657.

The Sadeian Woman is read in conjunction with The Bloody Chamber and both are situated in relationship to the feminist debates on pornography that started during the mid-1970s in America. Among the most relevant issues discussed in this article we find sadomasochism and representation.

Warner, Marina. "That Which Is Spoken." London Review of Books, 8 November 1990: 21-22.

Review of The Virago Book of Fairy Tales, edited by Carter. Choice, style and narrative techniques are discussed.

\section{Short Stories}

Carter's short story collections - Fireworks (1974) and Black Venus (1985) - have received little attention from critics. A good number of short stories only appeared in journals, newspapers and miscellanies during Carter's lifetime - receiving no critical attention at all - and were collected for the fist time in Burning Your Boats (1995), which also includes an unpublished story: "The Snow Pavillon." Rushdie 2006 is, precisely, the introduction to this collection. Both Matus 1991 and Munford 2004 concentrate on the demystifying and demythologizing potential of Carter's treatment of Jeanne Duval in "Black Venus." Dimovitz 2010 (cited under "Psychoanalysis") offers a psychoanalytic reading of "Flesh and the Mirror," a short story published in Fireworks.

- Matus, Jill. "Blonde, Black and Hottentot Venus: Context and Critique in Angela Carter's 'Black Venus'." Studies in Short Fiction 28 (1991): 467-475.

Perceptively shows how, in the short story "Black Venus," Carter questions the distorting versions of Jeanne Duval Baudelaire offered in his oeuvre, without presuming to appropriate Jeanne's story. The narrative voice, by unceasingly disputing its own authority, simply draws attention to other possible representations of Jeanne.

- Munford, Rebecca. "Re-presenting Charles Baudelaire/Re-presencing Jeanne Duval: Transformations of the muse in Angela Carter' 'Black Venus'." Forum for Modern Language Studies 40.1 (2004): 1-13.

Examines Angela Carter's "Black Venus" as an intertextual re-working of Baudelaire's representation of Jeanne Duval as muse in Les Fleurs du Mal, and identifies the story as crucial in understanding Carter's position towards her predominantly male French literary influences and intertexts.

- Rushdie, Salman. "Introduction." In Angela Carter. Burning Your Boats. Collected Stories, 3-15. London: Vintage Books, 2006.

A very acute, but synthetic, survey of Carter's shorter fiction (both fairy tales and short stories), which also contains a poignant recollection of the author's last moments (Carter and Rushdie were close friends) and a lapidary assessment of "the value of her unique oeuvre."

Scholars have unfortunately devoted little attention to Carter's substantial and eclectic body of journalism, a selection of which was published first in Nothing Sacred (1983) and then, posthumously, in Expletives Deleted (1992), which Carter prepared herself, and in Shaking a Leg (1998). One of the first discussions of the author's idiosyncratic journalistic style, so similar to her fictional style in its pungent and hilarious irreverence, is offered in Paulin 1983. On the other hand, The Sadeian Woman has, at times, found favour with criticism for its unconventional and revisionist treatment of a feminist bugbear. For instance, it is almost invariably dealt with in monographs, collections and interviews, in conjunction with Carter's fiction. In addition, it has often provided tools for analyses of the novels (Caputo 2002, cited under "The Passion of New Eve") and fairy tales (Sheets 1991, cited under "Fairy Tales"). Henstra 1999 reads Carter's controversial text as a model of "performative reading." Rubinson 2000 (cited under "Feminism") and Sage 2001 (cited under "Carter in the Panorama of Contemporary Fiction") look at the role of The Sadeian Woman in Carter's career, while Tonkin 2012 (cited under "Monographs") focuses on its decadent intertextual network. Robinson 1991 (cited, again, under "Carter in the Panorama of Contemporary Fiction") relies also on this text to set up a dialogue between feminist critical theory and contemporary women's fiction.

Henstra, Sarah M. "The Pressure of New Wine: Performative Reading in Angela Carter's The Sadeian

Woman." Textual Practice 13. 1 (Spring 1999): 97-117.

Starting from the difference between reading older texts, as Carter does in The Sadeian Woman, and rewriting them, as she does in her fictional works, the article identifies the essay on Sade as a model of "performative reading" that confronts a misogynistic cultural authority and shows it as vulnerable to a redeployment of meaning. 
- Paulin, Tom. "In an English Market." London Review of Books, 3-17 March 1983: 19.

Review of Nothing Sacred in which the style of Carter's journalism is examined.

○

Radio, Film and Television

Scant critical attention has been paid to Carter's numerous radio plays, both the adaptations of her short stories and the original radio dramas. Her controversial television documentary, The Holy Family Album (1991), her libretto for an opera based on Virginia Woolf's Orlando, her unproduced stage play (Lulu) and screenplays (Gun for the Devil and The Christchurch Murders) have been almost totally neglected. They were collected in The Curious Room (1996), all but The Holy Family Album that, according to Susannah Clapp, who wrote the introduction, would have "lost too much without pictures and colours and animation." Unfortunately, the volume, is not provided with and introduction to the individual works. Crofts 2003 offers a comprehensive survey of Carter's production for the different media, as also Di Luzio 2008 does. However, the former also incorporates sections dealing with media theory, while the latter includes TV criticism in the analysis. On the other hand, Anwell 1988, Collick 1991, Neale 1996 and Zucker 2000 are concerned with the films based on Carter's works. Anwell and Neale (who also discusses The Magic Toyshop) are critical, but curiously on opposite grounds. Collick makes reference to psychoanalysis, while Zucker examines Neil Jordan's film in detail.

Anwell, Maggie. "Lolita Meets the Werewolf: The Company of Wolves." In The Female Gaze: Women as Viewers of Popular Culture, 76-85. Edited by Lorraine Gamman and Margaret Marshment. London: Women's Press, 1988.

The film is criticized for an excessive exploitation of cinema's potential for illusion that detracts from the feminist power and the imaginative subtlety of the original tale. Anwell argues that the film concedes too much to market forces and fails as an adaptation.

Collick, John. "Wolves Through the Window: Writing Dreams/Dreaming Films/Filming Dreams." Critical Survey 3 (1991): 283-289.

The article discusses films of texts that revolve around dreams or dreaming. As far as Neil Jordan's The Company of Wolves is concerned, Collick sees it as a sort of "parody of the Freudian dream work in which the dream symbols, instead of being scrambled images or 'puzzles' that represent unconscious wishes, turn out to be familiar literary images."

- Crofts, Charlotte. Anagrams of Desire: Angela Carter's Writing for Radio, Film and Television. Manchester:

Manchester University Press, 2003.

Intelligent survey of Carter's large, but neglected body of writing for media other than the printed page. Each of the three sections is devoted to a different medium and opens with a chapter that explores the specific properties of that medium. Current critical and theoretical debates are also addressed.

- Di Luzio, Alessandra. La visione persistente: percorsi intertestuali e intermediali nella scrittura di Angela

Carter. Bologna: Patron, 2008.

In Italian. It focuses on the texts Carter produced for the media and on the media; namely screenplays, radio plays, drama and TV criticism. II also examines those elements in her production in general that were directly inspired by visual arts and performing arts.

Neale, Catherine. "Pleasure and Interpretation. Film Adaptations of Angela Carter's Fiction." In Pulping

Fictions: Consuming Culture Across the Literature/Media Divide, 99-109. Edited by Deborah Cartmell, I.Q.

Hunter, Heidi Kaye and Imelda Whelehan. London: Pluto Press, 1996.

Critical of Carter's films, which Neale sees first and foremost as adaptations that remain trapped in their literary origins and are not able to use the distinctive possibilities that cinema offers.

- Zucker, Carole.: "'Sweetest Tongue Has Sharpest Tooth': The Dangers of Dreaming in Neil Jordan's The

Company of Wolves." Literature/Film Quarterly 28.1 (2000): 66-71.

Interesting presentation of the transmogrification of the tale of Little Red Riding Hood over time and close reading of Neil Jordan's 1987 film The Company of Wolves.

\section{- The Gothic}

The Gothic is pre-eminent among the narrative genres that Carter demystified and re-invented in order to make them "speak the female," and criticism soon became aware of this, as Punter 1996 (originally published in 1980 ) shows. Now Carter is regularly included in surveys of the genre, and Jordan 2009 is given as an example of this trend. Farnell 2009 chooses "The Lady of the House of Love" as a point of departure for illustrating a new theory of the Gothic. Both Neumeier 1996 and Peng 2004 deal with the complexity of Carter's Gothicism, connecting it to postmodernism and gender issues. Munford 2002 and 2007 concentrate on Carter's Gothic heroines, while Sceats 2001 focuses on vampirism. Carter's relation to the Gothic is also explored in monographs (Peach 1998) and collections (Munford 2006). The programmatic use of the Gothic in Heroes and 
Villains is illustrated in Yoshioka 2006 (cited under "Early Novels up to 1972"), whereas the presence of the Gothic in Nights at the Circus is also discussed in Caputo 2010 (cited under "Nights at the Circus").

Farnell, Gary: "The Gothic and the Thing." Gothic Studies 11.1 (2009): 113-123.

In an attempt to advance a new theory of the Gothic, in which 'Gothic' is the name for the speaking subject's confrontation with intimations of the 'Thing' (das Ding), which stands for the absolute otherness described in the writings of Jacques Lacan, the article stimulatingly re-reads Angela Carter's story "The Lady of the House of Love."

- Jordan, Elaine. "Angela Carter." In The Handbook of the Gothic, $2^{\text {nd }}$ Edition, 17-20. Edited by Mary Mulvey-

Roberts. New York, NY: New York University Press, 2009.

Entry in what is virtually an encyclopedia of this elusive genre that offers a valuable, comprehensive and up-todate guide to Gothic writing, culture and currents.

- Munford, Rebecca. "Re-vamping the Gothic: Representations of the Gothic Heroine in Angela Carter's

Nights at the Circus." Paradoxa: Studies in World Literary Genres 17 (2002): 235-256.

The characterization of Fevvers, who is seen as a rather conventional Gothic heroine, in spite of her wings, is not completely convincing, but the extensive and detailed examination of the many Gothic spaces in the novel is nonetheless quite interesting.

Munford, Rebecca. 'The Desecration of the Temple'; or, 'Sexuality as Terrorism'?: Angela Carter's (Post-) feminist Gothic Heroines." Gothic Studies 9.2 (November 2007): 58-70.

Through a discussion of Carter's gothic heroines from Shadow Dance (1966) to Nights at the Circus (1984), the article re-contextualizes Carter's engagement with the Gothic as a dialogue with both the female Gothic tradition, which dates back to the eighteenth century, and feminist discourse.

- Neumeier, Beate. "Postmodern Gothic: Desire and Reality in Angela Carter's Writing." In Modern Gothic: $A$

Reader, 141-151. Edited by Victor Sage and Allan Lloyd Smith. Manchester: Manchester University Press, 1996.

Discusses the varied ways in which Carter uses Gothicism - especially in The Infernal Desire Machines of Doctor Hoffman - in order to explore issues connected to the nature of desire and reality. The essay also points out how the Gothic enables Carter to connect fairy tale and pornography and discuss gender issues.

- Peng, Emma Pi-tai . "Angela Carter's Postmodern Feminism and the Gothic Uncanny." NTU Studies in

Language and Literature. 13 (2004): 99-134.

In this substantial study, Peng discusses a number of texts by Carter to show their complex dialectics between feminism, postmodernism and the Gothic, and notes how "the sharp edge of her writing has come, for a large part, from her use of the Gothic."

- Punter, David. The Literature of Terror: A History of Gothic Fiction from 1765 to the Present Day. Volume 2,

The Modern Gothic. London - New York: Longman, 1996.

Originally published in 1980 (in one volume), this was the first important study to deal with the presence of the Gothic in Carter's fiction.

Sceats, Sarah. "Oral Sex: Vampiric Transgression and the Writing of Angela Carter." Tulsa Studies in

Women's Literature 20.1 (Spring 2001): 107-121.

Intriguingly investigates how, both in her rewritings of folk- and fairy-tales and in her more realist fiction, Carter plays with vampirism, using vampiric tropes and suggestions to explore gendered behavior and heterosexual power relations, and to probe the murky recesses of the contemporary psyche, highlighting what is usually covert, taboo, or suppressed.

\section{- $\quad$ Magic Realism}

John Haffenden opened his 1985 interview to Angela Carter stating that "the term 'magical realist' might well have been invented to describe Angela Carter, novelist, journalist, feminist." However, Carter's belonging to this narrative mode, like that of other authors writing from the geographical "center," has been far from undisputed. Zamora and Faris were the first to place the connection between Carter and magic realism into a broader (European) context, in 1995. Then, in recent years, Hegerfeldt 2002, Bowers 2004, Punter 2005 and Sceats 2005 followed. The issue is also dealt with in Caputo 2010 (cited under "Nights at the Circus") and Armitt 2000 (cited under "Carter in the Panorama of Contemporary Fiction") with regard to Nights at the Circus.

- Bowers, Maggie Ann. Magic(al) Realism (The New Critical Idiom). London: Routledge, 2004.

In one of the chapters dealing with the European appropriations of the genre - where magical realism is chosen as a means of experimentation - Bowers argues that the feminist Carter uses magical realism as her "means of attack," especially in Wise Children.

Hegerfeldt Anne. "Contentious Contributions: Magic Realism Goes British." Janus Head 5.2 (Fall 2002): 6286. 
Starting from a subtle analysis of "magic realist techniques and their functions," the article examines three texts (for Carter, Nights at the Circus) that have a Western context of production, and connects them to more "canonical" magic realist texts. A simplistic overlapping of "magic realism" with "postmodernism" is avoided. Rich bibliography.

Punter, David. "Angela Carter's Magic Realism." In The Contemporary British Novel since 1980, 48-58.

Edited by James Acheson and Sarah C.E. Ross. Edinburgh: Edinburgh University Press, 2005.

Taking its cue from a "standard" definition of magic realism, the essay perceptively explores a number of issues concerning Carter's unconventional and peculiar magic realism, in which characters "often seem as though they are characters from somebody else's story."

Sceats, Sarah. "Flights of Fancy: Angela Carter's Transgressive Narratives." In A Companion to Magical

Realism, 142-150. Edited by Stephen M. Hart and Wen-Chin Ouyang. Woodbridge: Tamesis, 2005.

Examines Carter's revisionist fairy tales and Nights at the Circus to show how the author's aim in using fantasy and symbolism is to present a deliberately disturbing and destabilizing view of what is real. Clear and to the point in approaching a controversial issue such as Carter's "affiliation" to magic realism.

Zamora Lois Parkinson and Wendy B. Faris, eds. Magical Realism: Theory, History, Community. Durham

NC: Duke University Press, 1995.

The introduction sets the ground noticing how, since the early 1980s, the term magical realism has been extended to include European (postmodernist) writers. Then, in their chapters, D'haen and Delbaere-Garant proceed to investigate how Carter's narrative strategies (in Nights at the Circus and in The Infernal Desire Machines of Doctor Hoffman) can be directly related to her magical realism.

\section{- $\quad$ Feminism}

References to feminism are, obviously enough, omnipresent in discussions of Carter, since she was seriously and unfalteringly committed to undermine and overturn patriarchal models, and envisage new possibilities for women. For this category, however, a number of studies have been selected where the feminist discourse takes center stage, and Carter's writing is also connected to feminist theory. This is true for Bristow-Broughton 1997 and Fernihough 1997. On the other hand, Trevenna 2002 contests precisely the excessive dependence of Carter's criticism on Butler's theories. Clark 1987 is critical of Carter and sees her writings as reinforcing patriarchy, instead of countering it. Such a view is contested in Jordan 1992, which aims exactly at defending Carter from such charges. Palmer 1987 and Rubinson 2000 trace the evolution in Carter's fictional treatment of gender issues.

Bristow, Joseph, and Trev Lynn Broughton, eds. The Infernal Desires of Angela Carter: Fiction, Femininity, Feminism. London \& New York: Longman, 1997.

Relying on contemporary feminist theory, the essays in this collection explore Carter's multifarious engagement with female desire, from her earliest writings to her posthumous ones. Carter's commitment to non-realist modes is also investigated. The collection can be useful also to those who have an interest in women's studies.

- Clark, Robert. "Angela Carter's Desire Machine." Women's Studies: An Inter-disciplinary Journal 14 (1987): 147-161.

Critical of Carter, who is accused of falling back into reinscribing patriarchal attitudes, instead of offering her readers possibilities of liberating consciousness. In her fictions, Carter would simply repeat the self-alienation imposed by the patriarchal system of power relations.

Fernihough, Anne. "Is She Fact or Is She Fiction?': Angela Carter and the Enigma of Woman." Textual Practice 11.1 (1997): 89-107.

Reads Nights at the Circus as a novel about feminist theory. Relying on Judith Butler's concept of performativity, it argues that the novel is engaged in a replacement of a truth-based model of gender and identity with a model based on repetition, iterability, as "Fevvers' identity is constituted in and through performance."

- Jordan Elaine. "The Dangers of Angela Carter." In New Feminist Discourses. Critical Essays on Theories and Texts, 119-131. Edited by Isobel Armstrong. London-New York: Routledge, 1992.

Deft defense of Carter's fiction from a number of charges, from decadence to a re-inscription of patriarchal norms. Jordan is also original in seeing a continuity between Nights at the Circus (which has almost unanimously been saluted as a new start for Carter) and her previous fiction.

Palmer, Paulina. "From 'Coded Mannequin' to Bird Woman: Angela Carter's Magic Flight." in Women Reading Women's Writing, 179-205. Edited by Sue Roe. Brighton: Harvester Press, 1987.

Acute survey of Carter's fiction that identifies a shift from an analytic, demythologizing impulse - in which the stress is on the representation of male authority - to a celebratory, utopian one. Starting from The Bloody 
Chamber (1979) onwards, the emphasis is no longer on women's alienation, but on women's possibilities of change.

Rubinson, Gregory J. "'On the Beach of Elsewhere': Angela Carter's Moral Pornography and the Critique of

Gender Archetypes." Women's Studies: An Inter-disciplinary Journal 29.6 (September 2000): 717-740.

Sees Carter's writing as an evolution from the concept of "moral pornographer" sketched out in The Sadeian Woman, and The Passion of New Eve as Carter's most explicit attempt to draft her "moral pornography" and thereby criticize mythologized notions of femininity.

Trevenna, Joanne. "Gender as Performance: Questioning the 'Butlerification' of Angela Carter's Fiction." Journal of Gender Studies 11.3 (2002): 267-276.

Contests the excessive reliance on Judith Butler's theories on the performativity of gender in criticism of Carter's fiction during the 1990s. While admitting the pertinence of such theories, the article highlights the differences that are nonetheless present between Butler's and Carter's presentations of gender acquisition.

\section{- $\quad$ Psychoanalysis}

Classical psychoanalytic theories (Freud's and, even more, Lacan's) are an indisputable presence in Carter, who relentlessly demystifies and questions their sexism. This is why criticism has so often had recourse to psychoanalysis to discuss how issues of subject and gender identities are explored in Carter's fiction. The works that have been favored by this kind of approach are, unsurprisingly: The Infernal Desire Machines of Doctor Hoffman, The Passion of New Eve, Nights at the Circus, and her subversive fairy-tales. Punter 1984 and Schmidt 1989 are the first important enquiries into Carter's mischievous attempts to "decolonize" the unconscious, while Dimovitz 2009 and 2010 are more recent investigations of Carter's feminist psychoanalytic rewritings. Based on psychoanalytic theories is also Farnell 2009 (cited under "The Gothic"), which provides an analysis of "The Lady of the House of Love" that draws on Lacan's the Thing (das Ding). On the other hand, Collick 1991 (cited under "Radio, Film and Television") reads the film The Company of Wolves as a parody of Freud, and Pérez-Gil 2007 (cited under The Passion of New Eve) looks at how Carl Jung's theories are subverted in The Passion of New Eve.

Dimovitz, Scott. "Angela Carter's Narrative Chiasmus. The Infernal Desire Machines of Doctor Hoffman and The Passion of New Eve." Genre 42 (Spring/Summer 2009): 83-112.

Argues that in The Infernal Desire Machines of Doctor Hoffman and The Passion of New Eve Carter "systematically incorporates and rewrites the psychoanalytic stage theories of Sigmund Freud, Melanie Klein, and Jacques Lacan as allegorical narrative structures," making explicit the workings of psychoanalytic theory in the reproduction of patriarchy.

Dimovitz, Scott. "I Was the Subject of the Sentence Written on the Mirror: Angela Carter's Short Fiction and the Unwriting of the Psychoanalytic Subject." Lit: Literature Interpretation Theory 21.1 (2010): 1-19.

Starting from Carter's problematic reception in America, it examines her short fiction of the 1970s (namely, "Flesh and the Mirror" and "Wolf Alice") in relation to psychoanalytic models of identity formation.

- Punter, David. "Angela Carter: Supersessions of the Masculine." Critique: Studies in Modern Fiction 25.4 (Summer 1984): 209-222.

Comparative reading of The Infernal Desire Machines of Doctor Hoffman and The Passion of New Eve where Punter traces a "principal shift of attention" in the dramatizations of the constructed subject, with sexuality and gender as structuring principles in the later text.

Schmidt, Ricarda. "The Journey of the Subject in Angela Carter's Fiction." Textual Practice 3.1 (Spring 1989): 56-75.

In-depth exploration of how the adventures the characters in The Infernal Desire Machines of Doctor Hoffman, The Passion of New Eve and Nights at the Circus meet on their journeys "mediate a discussion of the making of the subject in the light of philosophical, psychoanalytical, and feminist ideas."

\section{- $\quad$ Postmodernism and History}

The issue of Carter's adherence to a postmodern poetics has given rise to heated critical debates. This because Carter's commitment to socialism and feminism is undeniably antithetical to an idea of postmodernism as empty, self-reflexive play devoid of any ideological engagement. Nevertheless, Carter's fiction shows unmistakably postmodern features, such as its thick network of intertextual references, its demystifying revisionism and its delighting in parody and pastiche. However, reconciling political commitment and postmodernism has not always seemed impossible, and, indeed, Carter is particularly close to Linda Hutcheon's view of postmodernism as "resolutely historical and inescapably political." The texts in this category instance the debate over the advisability of defining Carter as a postmodernist tout court: a cogent discussion of the complex nature of postmodernism and of Carter's role in it can be found in Wilson 1989. Michael 1994 stops short of labeling Nights at the Circus as "postmodern," although it insists that Carter uses strategies that 
have often been connected to postmodernism. On the other hand, Day 1998 (cited under "Monographs") rejects critical associations with postmodernism altogether, because of Carter's engagement with material history. Carroll 2002, instead, regards Nights at the Circus as "an exemplary postmodern text" that deals with the textuality of history. Similarly, Berni 1997 reads one of Carter's short stories as laying the foundations for a postmodern historiography. Pitchford 2002 engages with Carter (and other women writers) precisely to assert the political and cultural value of postmodernism. Jordan 1992b and Rubinson 2005 equally focus on the political value of Carter's genre transgressing and demythologizing enterprise. Conversely, Manlove 1992 (cited under "Early Novels up to 1972") reads The Infernal Desire Machines of Doctor Hoffman as a disengaged postmodern attempt. Finally, Botescu-Sireteanu 2010 puts Carter's shift in narrative strategies in the context of postmodern ontological concerns.

Berni, Christine. "Taking an Axe to History: The Historical Lizzie Borden and the Postmodern Historiography of Angela Carter." CLIO: A Journal of Literature, History, and the Philosophy of History 27.1 (1997): 29-55.

The short story "The Fall River Axe Murders" is perceptively read as a commentary on past retellings tout court, as a challenge - by means of strategies often labeled as "postmodern" - to a kind of writing that disguises ideology through claims of fidelity to the real.

- Botescu-Sireteanu Ileana. "Angela Carter and the Violent Distrust of Metanarratives." Postmodern Openings 1.3 (September 2010): 93-138.

Traces Carter's shift from simple linear plots in her first three novels to spider-web plots in her following novels, which expand "circularly in various directions, covering at once a huge number of temporal instances and spatial locations." The connection between narrative strategies and gender issues is stimulating.

Carroll, Rachel. "Return of the Century: Time, Modernity, and the End of History in Angela Carter's Nights at the Circus." The Yearbook of English Studies. 30 (2000):187-201.

The novel is seen as an "exemplary" postmodern achievement that self-consciously evokes the textuality of history. Relying on Gianni Vattimo's theories, for Carroll the novel's postmodernity consists in its peculiar treatment of time, which disrupts linearity.

- Jordan, Elaine. "Down the Road, or History Rehearsed." In Postmodernism and the Re-reading of Modernity, 159-179. Edited by Francis Barker, Peter Hulme and Margaret Iversen. Manchester: Manchester University Press, 1992b.

Focusing primarily on The Infernal Desire Machines of Doctor Hoffman, The Passion of New Eve and Nights at the Circus, Jordan explores how Carter's demythologizing works for the empowerment and liberation of women by illuminating the blind spots of Enlightenment.

Michael, Magali Cornier. "Angela Carter's Nights at the Circus: An Engaged Feminism via Subversive

Postmodern Strategies." Contemporary Literature, 35.3 (Autumn 1994): 492-521.

Reprinted as "Fantasy and Carnevalization in Angela Carter's Nights at the Circus." In Feminism and the Postmodern Impulse: Post-World War II Fiction, 171-208. Edited by Magali Cornier Michael. Albany, N.Y.: SUNY Press, 1996.

Clever attempt to reconcile Marxist feminist realism and postmodernism (which have traditionally been considered incompatible) through the negotiation the novel carries out between realism and materialism on the one hand, and postmodernism, fantasy and the carnival on the other. In fact, these are used "to destabilize existing norms" and the binary logic that dominates Western culture.

Pitchford, Nicola. Tactical Readings: Feminist Postmodernism in the Novels of Kathy Acker and Angela

Carter. Lewisburg, PA: Bucknell University Press, 2002.

Focused on "the potential of feminist politics in the work of postmodernist women writers," it wants to revisit the debates that have taken place in the past decades over the political and cultural value of postmodernism paying more attention to the work of women, invariably neglected. This would redefine postmodernist practice in general.

Rubinson, Gregory J. The fiction of Rushdie, Barnes, Winterson, and Carter: Breaking Cultural and Literary Boundaries in the Work of Four Postmodernists. Jefferson, NC - London: McFarland, 2005: 147-186.

Carter is picked out as "the more daring, more inventive, and more incisively critical of social injustices" of the authors discussed in the study, and her writings are explored as inquiries into and critiques of social values through highly self-conscious and innovative experiments with genres.

Wilson, Robert Rawdon. "Slip Page: Angela Carter, In/Out/In the Postmodern Nexus." Ariel: a Review of International English Literature 20.4 (October 1989): 97-114.

Acute reflection on postmodernism, its double interpretation in theory and its problematizing of boundaries and categories, and on Carter's "Lady of the House of Love," in which (like in all the stories in the collection) playful self-reflexivity and historicity make the two seemingly incompatible postmodern archives overlap and coincide. 
All the texts in this category deal with Nights at the Circus, since it is here that the carnivalesque and the grotesque take center stage. Indeed, some of the settings of the story - namely, Mme Schreck's freak show and the circus - directly invite critical analyses that are based on Mikhail Bakhtin's work. The same is true for the gigantic and voracious protagonist, Fevvers. Besides, all the articles in this category highlight how the grotesque and the carnivalesque in Carter become functional to the feminist cause. Dennis 2008 focuses precisely on Fevvers's appetite and relates it to gender issues. On the grotesque dimension of the protagonist and the feminist potentialities of her deviancy are also centered Peterson 1996 and Russo 1995. Edwards 1998, instead, sees how Carter re-visits the idea of the carnivalesque in the novel. Turner 1987 uses Bakhtin to trace Fevvers's (and Walser's) personal transformation. Caputo 2010 (cited under "Nights at the Circus") investigates the novel as a whole - characters, images and situations - in the light of the carnival and the grotesque.

- Dennis, Abigail. "'The Spectacle of Her Gluttony': The Performance of Female Appetite and the Bakhtinian

Grotesque in Angela Carter's Nights at the Circus." Journal of Modern Literature 31.4 (2008): 116-30.

Starting from a revealing passage in the unpublished manuscript version of Nights at the Circus which testifies to the centrality of the body and its appetites the in the economy of the novel, the article explores how Fevvers's huge body and appetite, expressions of the Bakhtinian grotesque, are means through which existing gender and power relationships are challenged.

- Edwards, Brian. "Revisioning the Carnivalesque: The Cultural Combinations of Angela Carter's Nights at the Circus." In Theories of Play and Postmodern Fiction, 217-246. New York: Routledge, 1998.

Nights at the Circus is read as a feminist revision of contemporary carnivalesque. Here, a traditional figure of play, the circus, is a place both of distraction and of renovation in which woman is given active agency and laughter serves serious purposes.

- Peterson, Shirley. "Freaking Feminism: 'The Life and Loves of a She-Devil' and 'Nights at the Circus' as Narrative Freak Shows." In Freakery: Cultural Spectacles of the Extraordinary Body, 291-301. Edited by R.

Garland Thomson. New York: New York University Press, 1996.

It looks at how Carter and Weldon "enlist freakishness for the feminist agenda." Fevvers and Ruth are such deviant representations of femininity that they upturn all existing standards upon which traditional distinctions of gender rely. In the end, however, Peterson values the novel not for its endorsement of innovative gender politics, but simply for the ways it rumbles orthodoxies.

Russo, Mary. The Female Grotesque: Risk, Excess and Modernity. London, Routledge: 1995.

Emphasizes how Fevvers's grotesquely deformed female body can offer "endless possibilities for change." She becomes an embodiment of becoming, but, as such, she can only suggest progress without truly turning out to be an utopian figure who can positively escape patriarchy.

- Turner, Rory P.B. "Subjects and Symbols: Transformations of Identity in Nights at the Circus." Folklore Forum 20.1/2 (1987): 39-60.

A study of the novel that focuses on its ritual structure and symbolism. Based on Mikhail Bakhtin's ideas of the grotesque and the carnival.

\section{- $\quad$ Carter and Other (Women) Writers}

Articles and books comparing Carter to other women writers, mostly British, have appeared for a couple of decades now. However, the oldest article selected in this category is a German one, Mohr 1995, and it is unique in its focusing on progressive female behavior in different centuries and, in the case of Schreiner, in different cultures as well. Gruss 2009 is original in reading Carter in parallel with Michèle Roberts. The other studies are quite homogeneous in their choice of the writers, even if the novels they select for the comparisons differ. In fact, Carter is compared to Jeanette Winterson in Hobbs 2004, in Kilic 2009, in López 2007, in Martin 1999, in Roessner 2002 and in Russell 2000. Martin 1999 and Russel 2000 add a third writer: Fay Weldon in both cases. However, their perspectives on the "monstrosity" of the novels' protagonists are opposite, since Martin 1999 sees it as limiting in view of the writers' feminist claims, while Russell 2000 sees it as empowering.

- Gruss, Susanne. The Pleasure of the Feminist Text: Reading Michèle Roberts and Angela Carter. Amsterdam - New York: Rodopi, 2009.

Intelligent exploration of the works of two writers who share comparable concerns and techniques. The study programmatically reads them in parallel and in contrast to each other, showing how, focusing on their similarities, without obscuring their differences, "can prove fruitful for investigation in the field of feminist writing in general."

Hobbs, Richard. Writing on the Body: Sex, Gender and Identity in the Fiction of Jeanette Winterson and Angela Carter. Nottingham: Paupers' Press, 2004. 
Slim volume that investigates (trans)gendered identity in Written on the Body and The Passion of New Eve, drawing on current debates on sexuality and established philosophies.

- Kilic, Mine Ozyurt. Gender-Bending Fantasies in Women's Writing: Fantastic in Angela Carter's The Infernal Desire Machines of Dr. Hoffman, Nights at the Circus and Jeanette Winterson's The Passion, The.PowerBook. Saarbrücken: VDM Verlag Dr. Müller, 2009.

Relying on a revisitation of Tzvetan Todorov's concept of hesitation between the marvelous and the uncanny, this insightful study shows how the fantastic mode is used subversively by Carter and Winterson to negate culturally dominant notions of reality, undermine patriarchal gender roles and transcend traditional sexual boundaries.

- López, Gemma. Seductions in Narrative: Subjectivity and Desire in the Works of Angela Carter and Jeanette Winterson. Amherst, NY: Cambria, 2007.

Original study that provides an exploration of desire and subjectivity in narrative through the scrutiny of Heroes and Villains and Oranges Are Not the Only Fruit. The analysis of the two texts shows "how desire allows the subject to imagine an alternative, utopian location where a narrative of the self, in all its multiplicity and ambiguity, might be effected."

- Martin, Sara. "The Power of Monstrous Women: Fay Weldon's The Life and Loves of a She-Devil (1983), Angela Carter's Nights at the Circus (1984) and Jeanette Winterson's Sexing the Cherry (1989)." Journal of Gender Studies 8.2 (July 1999):193-210.

This essay argues that the image of female power these novels offer through their "monstrous" protagonists is too limited and that women are offering a biased portrait of themselves, in which the exploration of their weaknesses is too narrow and the androphobism of their discourse is too marked. Original in judging the novels as "questionably" feminist.

- Mohr, Hans-Ulrich. "Drei Konstrukte weiblicher Verhaltensräune: Charlotte Smith, Olive Schreiner, Angela

Carter." AAA-Arbeiten aus Anglistik und Amerikanistik 20.2 (1995): 317-333.

In German. Comparison between three novels written in three different centuries, which thematize modes of female behavior that were (or are) considered progressive in their respective ages. The novel chosen for Carter is Wise Children. The behavioral patterns that are presented in the novels are connected to the contemporary models of reality on which they are founded.

- Roessner, Jeffrey. "Writing a History of Difference: Jeanette Winterson's Sexing the Cherry and Angela

Carter's Wise Children." College Literature 29.1 (Winter 2002): 102-122.

The novels are appropriately read together to make the two authors' distinct feminist perspectives concerning historiographic issues emerge, in spite of their common stylistic traits and thematic preoccupations. The texts are seen as "paradigmatic fictional attempts to challenge the gender stereotypes often upheld in traditional histories."

- Russell, Lorena. "Dog-Women and She-Devils: The Queering Field of Monstrous Women." International Journal of Sexuality and Gender Studies 5.2 (April 2000): 177-193.

Shows how the "monstrous" (because powerful and excessive) and "perverse" (because transgressive) female characters in Carter's, Winterson's and Weldon's fiction permit greater complexity in exploring possibilities of sexual subjectivity and identifications. In particular, they "open spaces for recasting a transgressive female heterosexuality through a formulation of the queer."

\section{- $\quad$ Carter in the Panorama of Contemporary Fiction}

Unlike her contemporary Margaret Drabble, Carter was not included into Elaine Shawalter's 1977 A Literature of Their Own. Nor did she appear in Patricia Meyer Spacks's Contemporary Women Novelists, published that same year. It is upsetting that it took almost two decades after the publication of her first novel for Carter's fiction to find its way into collections, such as The Norton Anthology of Literature by Women (1985) edited by Sandra Gilbert and Susan Gubar. The only texts in this category that pre-date Carter's death are Alexander 1989, Palmer 1989 and Robinson 1991, and the surveys are limited to women novelists. Exclusively to women novelists are also devoted Sage 2001 and Armitt 2000, which focuses on the fantastic. Gasiorek 1995, Morrison 2003 (which is addressed to undergraduate readers) and Waugh 1995, at last, put Carter in the context of contemporary literature tout court.

- Alexander, Flora. Contemporary Women Novelists. London: Edward Arnold, London 1989: 63-75.

Ten contemporary British women novelists who began writing in the $60 \mathrm{~s}$ and 70 s are interestingly compared in the introduction, and then their fiction is arranged in three groups, broadly corresponding to "realism", "politics" and "fantasy." Carter's novels (up to Nights at the Circus) are discussed in the last section of the volume, called "Myths, Dreams and Nightmares."

- $\quad$ Armitt, Lucy. Contemporary Women's Fiction and the Fantastic. Basingstoke: Palgrave Macmillan, 2000. 
The volume focuses on the fantastic as employed by contemporary women novelists writing between 1965 and 1999. Carter's Nights at the Circus is placed in the context of magic realism, but on "the dark or underside of the magic real," which overlaps with the Gothic.

- Gasiorek, Andrzej. Post-War British Fiction: Realism and After. London: Edward Arnold, 1995.

While exploring the responses of a number of post-war British novelists to the legacy of modernism, Gasiorek interestingly investigates the operation of cultural deconstruction and subsequent bricolage on which Carter's whole fictional enterprise is based.

- Morrison, Jago. Contemporary Fiction. London: Routledge, 2003: 155-178.

Valuable guide for undergraduate readers approaching contemporary fiction for the first time. The chapter "Angela Carter: genealogies" focuses on Carter's problematic construction of history as inherited "meanings" (as opposed to "facts").

- Palmer, Paulina. Contemporary Women's Fiction. Narrative Practice and Feminist Theory. London: Harvester Wheatsheaf, 1989.

Accused of being biased (because written from a radical feminist perspective), nevertheless it offers a stimulating investigation of the relationship between contemporary fiction by British, American and Canadian writers, and feminist theory, both political and literary. Besides a theoretical "Introduction" and a "Conclusion," the volume is divided into seven political themes which Palmer identifies within her selection of fiction. Useful glossary.

- $\quad$ Sage, Lorna. Moments Of Truth: Twelve Twentieth Century Women Writers. London: Fourth Estate, 2001.

The essay on Carter (the last chapter in the book) importantly identifies 1979 (the year in which The Bloody Chamber and The Sadeian Woman were published) as a turning point in her career, an explanatory prism through which her earlier work suddenly became intelligible.

- Robinson, Sally. Engendering the Subject: Gender and Self-Representation in Contemporary Women's Fiction. New York: State University of New York Press, 1991.

Focused on the question of the subject position, the volume sets up a dialogue between feminist critical theory and contemporary women's fiction. It also interestingly suggests how such fiction can offer a model for an empowering feminist reading practice. Concerned with The Infernal Desire Machines of Doctor Hoffman, Nights at the Circus and The Sadeian Woman.

- Waugh, Patricia. Harvest of the Sixties: English Literature and Its Background, 1960-90. Oxford: Oxford University Press, 1995.

The study looks at the proliferation of voices in this period of great cultural and political change and development, and puts literature into context. The author, however, is critical of Carter and finds her gender politics unconvincing. 